\title{
Screening and Characterization of a Mutant Fungal Aspartic Proteinase from Mucor pusillus
}

\author{
Li Yuqiu, Tan Hua, Li Da, Li Zhoulin, Chi Yanping, Jiang Yuanyuan, Liu Xiangying, \\ Wang Jinghui" and Li Qiyun
}

Center of Agro-food Technology, Jilin Academy of Agricultural Sciences, Changchun, Jilin, 130033, P.R. China

\begin{abstract}
In this study, site-directed mutagenesis was carried out to alter properties of Mucor pusillus rennet (MPR) in order to find a potential substitution of commercial chymosin. Mutant G186D/E13D screened from thousands of mutants showed a significant milk-clotting activity (MCA). Mutant G186D/E13D rennet was purified and characterized. The molecular weight was estimated to be $44 \mathrm{kDa}$ by SDS-PAGE. The maximum enzyme activity was at a wide range of $\mathrm{pH}$ (5.0-7.0) and $60^{\circ} \mathrm{C}$. The enzyme was inhibited by metal ions $\left(\mathrm{Fe}^{2+}, \mathrm{Fe}^{3+}, \mathrm{Cu}^{+}\right.$and $\left.\mathrm{Zn}^{2+}\right), 1.10$-Phenantrolin and pepstatin A. Further texture analysis of types of cheddar cheese made by non-mutant rennet, mutant (G186D/E13D) rennet and commercial rennet suggested that the soluble nitrogen content and hardness of cheddar cheese made by chimeric mutant rennet was decreased without any significant change in flavor between these cheeses. The result implicated that, to some extent, the mutant rennet could decrease hydrolysis of protein during ripening of cheese, probably as a candidate for a useful milk coagulant.
\end{abstract}

Keywords: Aspartic proteinase, Mucor pusillus rennin, Mutation, Thermostability, Proteolytic activity.

\section{INTRODUCTION}

Chymosin is an aspartic proteinase (EC 3.4.23.4) that is responsible for the coagulation of milk in the fourth stomach (abomasum) of unweaned calves in the form of an inactive precursor prochymosin [1], which is used extensively in cheese production because it cleaves $\kappa$-casein in a specific manner, at the Phe105-Met106 bond, with low proteolytic activity, and for the production of quality cheeses with good flavor and texture [2]. Unavailability of calf stomach and ethical problems associated with animal slaughtering has necessitated the finding of other alternatives to calf chymosin. In this regard, various plants and microbial proteases alternatives are used for chymosin production. Plant sources for milk-clotting enzymes have been identified from Cynara scolymus [3], Carica papay [4], Streblus asper [5], Centaurea calcitrapa [6] and Albizia [7]. Unfortunately, most of these sources are not suitable for production of quality cheese as they produce a bitter taste [2]. Proposed microbial substitutes for animal proteases include those from fungi and bacteria, such as Basidiomycete [8], Mucor pusillus [9], Bacillus sphaericus [10], Rhizomucor pusillus [11], Rhizopus oryzae [12] and Aspergillus [13]. At present, microbial rennet is used for one third of the entire cheese produced worldwide [14].

Mucor rennins are an aspartic proteinase produced by two closely related strains of Mucorales fungi, Mucor pusillus and Mucor miehei $[15,16]$. These enzymes possess

\footnotetext{
*Address correspondence to these authors at the Center of Agro-food Technology, Jilin Academy of Agricultural Sciences, Changchun, Jilin, 130033, P.R. China; Tel: +86 43 87063260; Fax: +86 4387063062 ;

E-mail: 846812862@qq.com
}

similarly characterized milk-clotting characteristics to those of calf chymosin, and they have been used as substituting enzymes for calf chymosin in the cheese industry. However, these enzymes are more proteolytic than bovine chymosin, thus leading to a lower yield in the production of cheese due to continued proteolysis following milk coagulation. Additionally, during cheese ripening, the curd-entrapped enzyme remains active and further degrades casein fractions by extensive non-selective peptide bond attack. This phenomenon may also lead to bitter flavor and structural deficiencies in ripe cheese, even after the heat-treatment step often present in its processing [17]. Moreover, the enzyme fraction in the whey could degrade proteins of economic value [18].

Site-directed mutagenesis is a good tool to research on the relationship of structure and function of proteins, especially for researching on chymosin, to vary systematically the sequence of peptide substrates and also to vary the specificity subsites using site-directed mutagenesis [19-23]. Meanwhile, site-directed mutagenesis is also a good strategy to alteration and modification of sequence. We have cloned the preproRMPP gene, and have developed efficient expression systems for the enzymes as zymogens in Pichia pastoris [24]. By using this system, site-directed mutagenesis of many milk-clotting enzymes was carried out to generate mutant enzymes with amino acid exchanges at position 13, 101 and 186. The mutant enzyme was purified and characterized biochemically, and cheeses made by the enzyme were analyzed for textural parameters and proteolysis after cheese ripening. In this case, replacement of Glu13/Gly186 was found to cause a marked decrease in the proteolytic activity. 


\section{MATERIALS AND METHOD}

\subsection{Strains and Plasmids}

The MPR gene encoding preproMPR, cloned from the genome of Mucor pusillus consists of a pre-sequence of 22 amino acids for secretion, a pro-sequence of 44 residues and a mature enzyme of 362 residues [24]. The plasmid pPICZ $\alpha$ A, containing the MPR gene downstream of the AOX promoter, was introduced into Pichia pastoris GS115 (his4, lacZ) as a host to produce the wild-type and mutated MPR genes.

\subsection{Media and Culture Conditions}

YPD medium contained 2\% Bacto-peptone (Difco, USA), $1 \%$ Bacto-yeast extract (Difco). The yeast transformants were pre-cultured in YPD medium at $30^{\circ} \mathrm{C}$ for $24 \mathrm{~h}$. The cells were then harvested and re-suspended in 100 $\mathrm{mL}$ of BMMY medium containing $1.34 \%(\mathrm{w} / \mathrm{v})$ bacto-yeast nitrogen base, $1 \%$ yeast extraction, $2 \%(\mathrm{w} / \mathrm{v})$ peptone, $0.5 \%$ $(\mathrm{w} / \mathrm{v})$ biotin and $1 \%(\mathrm{v} / \mathrm{v})$ methanol. Cultivation was continued at the same temperature for an additional 5 days [25].

\subsection{Mutagenesis}

Site-directed mutagenesis was carried out using a Polymerase Chain Reaction mediated method. Substitutions were made by overlap extension PCR mutagenesis [20]. Five mutants Ala101Thr (A101T), Glu186Asp (G186D), Glu13Asp (E13D), Glu13Gln (E13Q) and Glu13Ala (E13A) were obtained by reverse overlap primers as shown in Table 1. All the mutations were checked by nucleotide sequencing and introduced into the corresponding position of pPICZ $\alpha \mathrm{A}$ by forming single mutants (A101T, G186D, E13D, E13Q, E13A and E13P) and chimeric mutants (A101T/G186D, A101T/E13D, G186D/E13D and G186D/E13Q). Transformation of Pichia pastoris was carried out by the electroporation method of Becher et al. 1991 [26].

\subsection{Screening}

Clotting activity determination of all transformants by microplate assay according to [20] was carried out using $4 \%$ $(\mathrm{w} / \mathrm{v})$ skim milk tempered to $35^{\circ} \mathrm{C}$. Clotting was measured as an increase in absorption at OD800, and the clotting activity calculated from a standard curve was obtained using serially diluted standardized unmutated MPR. Selected transformants were used for the shake flask experiments, which were transformant cultured in BMMY induced by methanol for 5 days at $30^{\circ} \mathrm{C}$ on orbital shaker at $220 \mathrm{rpm}$. The cells were harvested by centrifugation at $10,000 \mathrm{~g}$ for $20 \mathrm{~min}$ at $4^{\circ} \mathrm{C}$ and the supernatant (crude enzyme) was used for purification experiments [10].

\subsection{Purification of MPR}

The crude enzyme solution was precipitated at $80 \%$ saturation of (NH4)2SO4. The active fraction with high milk clotting activity (MCA) was further purified by passing through Sephadex G-100 column $(100 \mathrm{~cm} \times 1.2 \mathrm{~cm})$ pre-washed with 50 $\mathrm{mM}$ sodium phosphate buffer at $\mathrm{pH} 5.8$. Fractions of $5 \mathrm{ml}$ each were collected at room temperature at a flow rate of about 20 $\mathrm{ml} / \mathrm{h}$. The active fractions were dialyzed against distilled water and concentrated via lyophilization [9]. The concentrated enzyme was loaded on to a DEAE- $52(20 \mathrm{~cm} \times 1.6 \mathrm{~cm})$ preequilibrated with $50 \mathrm{mM}$ sodium phosphate buffer at $\mathrm{pH} 5.8$. Elution of protein was then carried out by batch-wise addition of $50 \mathrm{ml}$ portions of increasing molarities $(0.0-0.5 \mathrm{M})$ of $\mathrm{NaCl}$ in $50 \mathrm{mM}$ sodium phosphate buffer at $\mathrm{pH} 5.8$. Fractions of $5 \mathrm{ml}$ each were collected at room temperature $\left(25^{\circ} \mathrm{C}\right)$ at a flow rate of about $30 \mathrm{ml} / \mathrm{h}$ and analyzed for MCA and protein content [12]. The active enzyme fractions were pooled and stored at $4{ }^{\circ} \mathrm{C}$ for further studies. The purified proteinase was examined for protein by electrophoresis under denaturing conditions in $12 \%$ polyacrylamide slab gels $[17,27]$.

\subsection{Assay of Milk-Clotting Activity (MCA)}

The MPR was assayed using the method described by Arima et al. [11]. A 10\% solution of skim milk (Snow Brand

Table 1. Nucleotide sequences used for site-directed mutagenesis of Ala101, Gly186 and Glu13.

\begin{tabular}{|c|c|c|}
\hline \multirow{2}{*}{ Mutant Site } & Primers & Sequence of Mutant Primer \\
\hline \hline \multirow{3}{*}{101} & A101T-F & 5'CGGCGGTACGACCGTGAAG3' \\
\cline { 2 - 3 } & A101T-R & 5'CTTCACGGTCGTACCGCCG3' \\
\hline \multirow{5}{*}{186} & G186D-F & 5'GTCTTTGGTGACGTCAACAACACC3' \\
\cline { 2 - 3 } & G186D-R & 5'GGTGTTGTTGACGTCACCAAAGAC3' \\
\hline \multirow{5}{*}{13} & E13Q-F & 5' GACTTGGAGCAGTACGCCATTC3' \\
\cline { 2 - 3 } & E13Q-R & 5' GAATGGCGTACTGCTCCAAGTC3 \\
\cline { 2 - 3 } & E13D-F & 5' GACTTGGAGGACTACGCCATTC3' \\
\cline { 2 - 3 } & E13D-R & 5' GAATGGCGTAGTCCTCCAAGTC3' \\
\cline { 2 - 3 } & E13P-F & 5'GACTTGGAGCCGTACGCCATTC3' \\
\cline { 2 - 3 } & E13P-R & 5'GAATGGCGTACGGCTCCAAGTC3' \\
\cline { 2 - 3 } & E13A-F & 5' GACTTGGAGGCATACGCCATTC 3' \\
\cline { 2 - 3 } & E13A-R & 5'GAATGGCGTATGCCTCCAAGTC3' \\
\hline
\end{tabular}


milk products $\mathrm{Co}$.) containing $10 \mathrm{mM} \mathrm{CaCl} 2$ was used as the substrate. Substrate solution $(5 \mathrm{ml})$ was added to the enzyme solution $(0.5 \mathrm{ml})$ at $35^{\circ} \mathrm{C}$. The time required for curd particles to form was measured with a stop watch. Under the above assay condition, 1 unit of activity (Soxhlet Unit) was defined as the amount of enzyme that clotted the milk solution in 40 $\min [28]$.

\subsection{Assay of Proteolytic Activity (PA)}

The proteolytic activity was measured using a $1.0 \%$ solution of casein $(\mathrm{M} / 1050 \mathrm{mM}$ sodium phosphate buffer, $\mathrm{pH} 5.8)$ as the substrate. Five milliliters of the substrate solution was incubated with $1 \mathrm{ml}$ of enzyme solution at $45 \mathrm{oC}$ for $30 \mathrm{~min}$ and the enzyme reaction was stopped with $5 \mathrm{ml}$ of trichloroacetic aci mixture solution. After $30 \mathrm{~min}$ of incubation, the reaction mixture was filtered using filter paper and $2 \mathrm{ml}$ of the filtrate was added to $5 \mathrm{ml}$ of $0.55 \mathrm{M}$ $\mathrm{Na}_{2} \mathrm{CO}_{3}$ and $1 \mathrm{ml}$ of Folin's reagent. This mixture was measured. One unit of the activity was defined as the amount of enzyme, which released lug of amino acid expressed as the tyrosine concentration per min under the above condition [28].

\subsection{Effect of Temperature on Enzyme}

The effect of temperature on milk-clotting activity of MPR was studied by measuring the activity of the purified enzyme at different temperatures $\left(30-75^{\circ} \mathrm{C}\right)$.

The thermal stability of the purified enzyme was studied by measuring the milk-clotting activity of the residual enzyme after incubation for $0,10,20,30,40,50,60,90$ and $120 \mathrm{~min}$ at $55^{\circ} \mathrm{C}[3]$.

\subsection{Effect of pH on Enzyme}

The effect of $\mathrm{pH}$ on milk-clotting activity of the purified enzyme was studied at $\mathrm{pH}$ range of 5.0-8.0. The buffers used were: $0.1 \mathrm{M}$ citrate-phosphate $(\mathrm{pH} 5.0-6.0)$ and $0.1 \mathrm{M}$ sodium phosphate (pH 6.0-8.0) [11, 14].

The $\mathrm{pH}$ Stability of the enzyme was studied at $\mathrm{pH}$ values from 3.0 to 10.0 . The buffers employed were $50 \mathrm{mM}$ sodium citrate for $\mathrm{pH} 3.0,4.0$ and 5.0;50mM sodium phosphate for $\mathrm{pH} 6.0$ and $7.0 ; 50 \mathrm{mM}$ Tris/ $\mathrm{HCl}$ for $\mathrm{pH} \mathrm{8.0,9.0} \mathrm{and} \mathrm{10.0.}$ After incubation for $16 \mathrm{~h}$ at $25^{\circ} \mathrm{C}$, the residual enzyme activity was measured $[29,30]$.

\subsection{Effect of Metal Ions and Inhibitors}

The effect of some metal ions $\left(\mathrm{Ni}^{2+}, \mathrm{K}^{+}, \mathrm{Zn}^{2+}, \mathrm{Mg}^{2+}\right.$, $\mathrm{Mn}^{2+}, \mathrm{Cu}^{+}, \mathrm{Fe}^{2+}$ and $\mathrm{Fe}^{3+}$ ) at $5 \mathrm{mM}$ concentration and some inhibitors (o-Phenantrolin, Aprotinin, Leupeptin, phenylmethylsulphonyl fluoride (PMSF), EDTA and pepstatin A on purified enzyme activity was tested. The concentrations of the inhibitors are listed in Table 3 . The purified enzyme was incubated at room temperature for 30 minutes with metal ions or inhibitors and the residual milk-clotting activity was measured [31].

\subsection{Cheese Manufacture and Analysis}

Textural and proteolytic properties of cheese made with MPR were analyzed using a standard procedure [32]. Cheddar cheese was made with the mutant rennin (G186D/E13D)

The composition of the cheese was determined in triplicate. Fat content [33] and moisture content were determined [34]. The $\mathrm{pH}$ of the cheese was estimated [35].

The proteolysis of cheeses was assayed by determination of total nitrogen (TN), $\mathrm{pH} 4.6$ phosphotungstic acid-soluble nitrogen (PTASN) according to methods described by Christensen et al. [36]. Total protein content was then obtained by multiplying the TN value by 6.38 [37].

Texture profile analysis (TPA) was carried out of the cheeses according to the methods described by Bhaskaracharya RK [38]. All analyses were carried out thrice.

\subsection{Statistical Analysis}

The SPSS package (SPSS 12.0 for Windows, SPSS Inc. Chicago, ILand USA) was used for statistical analysis of the results. Analysis of variance (ANOVA) was undertaken and the mean was established for $\mathrm{P}<0.05$. Mean comparisons were performed according to the Tukey's honest significant differences (HDS) test. Thus, a, b, c superscripts were employed to state significant differences between the lots for the exact same ripening time [37].

\section{RESULT AND DISCUSSION}

\subsection{Screening of Mutant MPR}

To test the effect of mutations at positions A101, G186 and E13 on the thermostability and proteolytic activity of MPR, one or two of the residues were substituted in MPR and the chimeric mutants in Pichia pastoris were expressed $[11,24]$. The results of measurements for milk-clotting activity, proteolytic activity and thermostability of these mutants are presented in Table 2. The mutants' enzymes (A101T/G186D, G186D/E13D, G186D/E13Q, G186d/E13Q and A101T /G186) were shown to be more sensitive to thermos than that of the non-mutated enzyme, especially the double mutant A101T/G186D that lost milk-clotting by $50 \%$ when incubated for $40 \mathrm{~min}$ at $55 \mathrm{oC}$, but without any change in the proteolytic activity. When residues were exchanged in position E13, the proteolytic activity of all the mutants (E13P, E13Q, E13D and E13A) decreased remarkably to almost a half of that of non-mutant enzyme, but there was no change in thermostability. Chimeric mutants (G186D/E13D and G186D/E13Q) had a reduction in thermostability along with a sharp decrease in proteolytic activity. The mutant G186D/E13D was selected for further characterization as described below.

Generally, protein cores are typically hydrophobic. Hydrophobic interaction is considered as a dominant force in structural stability and increased packing efficiency is often correlated with increased hydrophobicity [39-41], therefore hydrophobic amino acids always exist in protein cores to keep the proteins stable. Hydrophobic amino acids (Ala and 
Table 2. Milk clotting and proteolytic activities of the non-mutant and mutant MPRs.

\begin{tabular}{|c|c|c|c|c|}
\hline Enzyme & 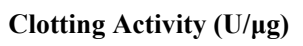 & 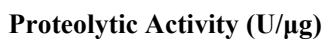 & $\mathrm{C} / \mathrm{P}$ ratio & Thermostability Relative Activity (\%) at $55^{\circ} \mathrm{C} 40 \mathrm{~min}$ \\
\hline Non-mutation & 10.19 & 2.83 & 3.6 & 88.6 \\
\hline $\mathrm{A} 101 \mathrm{~T}$ & 13.6 & 2.72 & 4.8 & 75.8 \\
\hline G186D & 16.63 & 2.64 & 6.3 & 58.6 \\
\hline E13P & 8.63 & 1.87 & 4.6 & 86.2 \\
\hline E13Q & 7.97 & 1.19 & 6.7 & 88.2 \\
\hline E13D & 8.38 & 1.18 & 7.1 & 89.1 \\
\hline E13A & 8.26. & 1.23 & 6.7 & 85.5 \\
\hline $\mathrm{A} 101 \mathrm{~T} / \mathrm{G} 186 \mathrm{D}$ & 16.24 & 2.62 & 6.2 & 53.5 \\
\hline G186D/E13D & 10.47 & 1.36 & 7.7 & 70.2 \\
\hline G186D/E13Q & 9.53 & 1.27 & 7.5 & 73.6 \\
\hline
\end{tabular}

Gly) at positions 101 and 186 were substituted by charged amino acids (Thr and Asp) respectively, which made it difficult to maintain hydrogen cores of rennet [42], finally leading to unstable or flexible conformation of MPR.

Site E13 in RMPP plays a critical role in forming the correct hydrogen bond network around the active center and influence catalytic rate of RMPP as reported by Aikawa [12]. Substitutions at position 13 exchanged residue from Glu to Asp to alter space conformation of MPR resulting in decreased affinity of the MPR to substrate. Simulation analysis and molecular docking analyzed by software found possibility that position 13 may be related to increased substrate specificity (Analysis by our colleague, data is not shown), which was later proved in this experiment and also in RMPP Aikawa in 2001.

\subsection{Purification of Mutated MPR}

The results pertaining to purification of mutated MPRs using a combination of different purification techniques are summarized in Table 3. After fermentation, the mutated MPR produced by recombinant Pichia pastoris GS115 was fractioned at $70 \%$ ammonium-sulphate with 1.3-fold purification and 91.6\% recovery. Passage through Sephadex G-75 column resulted in about 5.7-fold purification of the enzyme with specific activity of $17203 \mathrm{U} / \mathrm{mg}$. Finally, the concentrated active fractions passed through DEAE -52 column and the enzyme was purified about 7.1-fold with $5.2 \%$ recovery. Figs. $(1,2)$ show the elution diagrams of the mutant G186D/E13D using Sephadex G-75 and DEAE-52 columns, respectively. Purified MPRs were separated into two peaks of proteins with one activity peak on Sephadex G75 and one eluted activity peak (elution peak I) with 0.2 mol/L NaCl sodium phosphate buffer, pH 6.0 on DEAE-52. These peaks with MCA of proteins appeared as one band with molecular mass of $44 \mathrm{kDa}$ on SDS-PAGE (shown in Fig. 3).

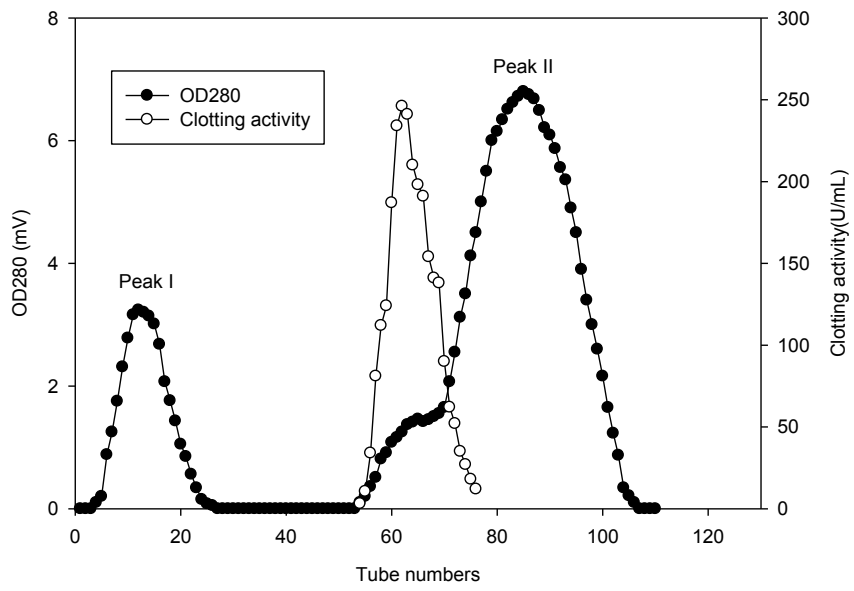

Fig. (1). Elution profile of mutant MPR on sephadex G-75 chromatography.

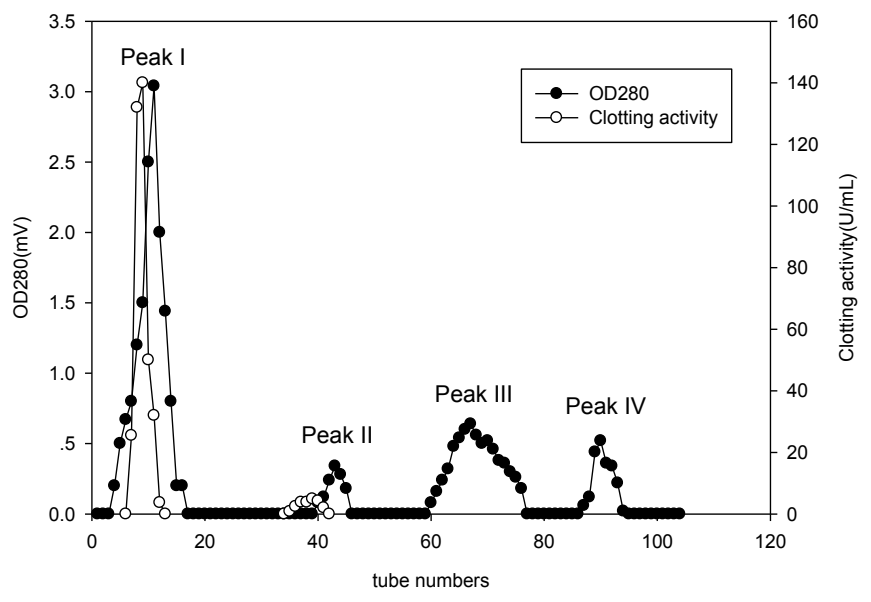

Fig. (2). Elution profile of mutant MPR on DEAE-52 chromatography. 
Table 3. Purification scheme of Mutant MPRs produced by Pichia pastoris.

\begin{tabular}{|c|c|c|c|c|c|c|c|c|}
\hline & $\begin{array}{c}\text { Volume } \\
(\mathbf{m L})\end{array}$ & $\begin{array}{c}\text { Clotting Activity } \\
\mathbf{( U / m L )}\end{array}$ & $\begin{array}{c}\text { Total Clotting } \\
\text { Activity (U) }\end{array}$ & $\begin{array}{c}\text { Protein Content } \\
(\mathbf{u g} / \mathbf{m L})\end{array}$ & $\begin{array}{c}\text { Total Protein } \\
\text { Content (mg) }\end{array}$ & $\begin{array}{c}\text { Specific Activity } \\
\text { (U/mg) }\end{array}$ & $\begin{array}{c}\text { Yield } \\
\mathbf{( \% )}\end{array}$ & $\begin{array}{c}\text { Purification } \\
\text { Fold }\end{array}$ \\
\hline \hline Crude extract & 100 & 83 & 8300 & 27.5 & 2.75 & 3018 & 100 & 1 \\
\hline (NH4) 2504 & 10.0 & 760 & 7603 & 193.7 & 1.94 & 3922 & 91.6 & 1.3 \\
\hline G-75 & 3.0 & 462 & 1386 & 26.9 & 0.081 & 17203 & 16.7 & 5.7 \\
\hline DE-52 & 3.0 & 144 & 432 & 6.7 & 0.022 & 21428 & 5.2 & 7.1 \\
\hline
\end{tabular}

\subsection{Effect of Temperature}

Purified mutant G186D/E13D and non-mutant enzymes acted optimally at $60^{\circ} \mathrm{C}$ and later, they started losing their activity rapidly leading to complete inactivation at $75^{\circ} \mathrm{C}$ (Fig. 5). The thermal inactivation experiments indicated that the mutant enzymes were slightly sensitive to heat than the non-mutant enzymes (Fig. 4), despite that MPR is a relatively thermostable protein. The non-mutated enzyme at $55^{\circ} \mathrm{C}$ remained almost fully active even after $60 \mathrm{~min}$ of incubation, but G186D/E13D lost $30 \%$ of its activity after 50 min at the same temperature.

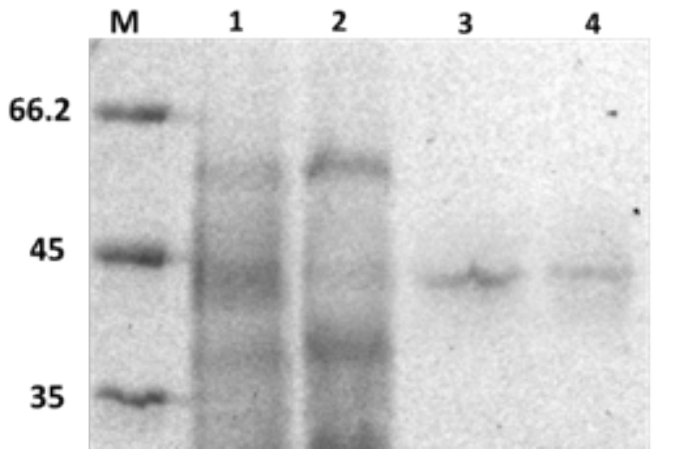

Fig. (3). Electrophoretogram of mutant MPR (G186D/E13D) after various steps of purification on SDS-PAGE of purification steps. Lane M: standard molecular weight markers; Lane1: Supernatant extract; Lane 2: (NH4)2SO4 fractionation; Lane 3: Sephadex G-75, Lane 4: DEAE-52.

Previously, the optimal temperature of MCA produced by Enterococcus faecalis TUA2495L [28] was $70^{\circ} \mathrm{C}$. The maximum MCA of purified enzyme produced by Rhizopus oryza [12] and Bacillus sphaericus [10] was at $60^{\circ} \mathrm{C}$ and $55^{\circ} \mathrm{C}$ respectively. The crude enzyme from Yeast Extracellular [29] showed maximum activity at $65^{\circ} \mathrm{C}$ with $10 \%$ of clotting activity lost at $60 \mathrm{~min}$ incubation at $45^{\circ} \mathrm{C}$.

\subsection{Effect of $\mathbf{p H}$}

Fig. (6) shows that the MCA of all of the mutant enzymes decreased as the $\mathrm{pH}$ increased from 5.0 to 7.5, and no activity was observed at $\mathrm{pH} 8.0$. The optimum $\mathrm{pH}$ for both the non-mutant and mutant enzymes was 5.5 and the same result has been reported by Ashwani for milk clotting protease from Capra hircus. The $\mathrm{pH}$ optimum of purified APs from C. calcitrapa cell suspensions was detected at $\mathrm{pH}$ 5.1 [43]. The milk-clotting enzyme from glutinous rice wine mash liquor exhibited maximal MCA in milk at a $\mathrm{pH}$ of 5.5 [14]. Initial enzyme activity remained stable after treatment at $\mathrm{pH} 6.0$, but there was an almost $50 \%$ loss in the activity at
pH 5.0 or 7.0 (Fig. 7). Sushil found that extracellular acid protease from Rhizopus oryzae [12] retained $96 \%$ of its activity at $\mathrm{pH} 5.5-7.5$.

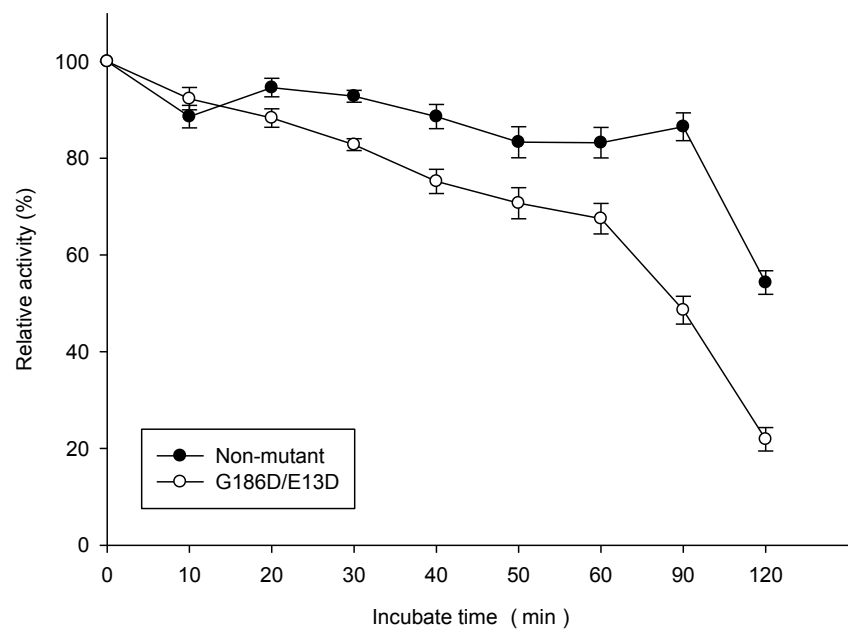

Fig. (4). Thermostability of purified non-mutant and mutant MPRs. Relative milk-clotting activities (\%) were determined between 10$120 \mathrm{~min}$ at $55^{\circ} \mathrm{C}$ for non-mutant $\mathrm{MPR}$ and mutant MPR $\mathrm{G} 186 \mathrm{D} / \mathrm{E} 13 \mathrm{D}$ produced by recombinant yeasts.

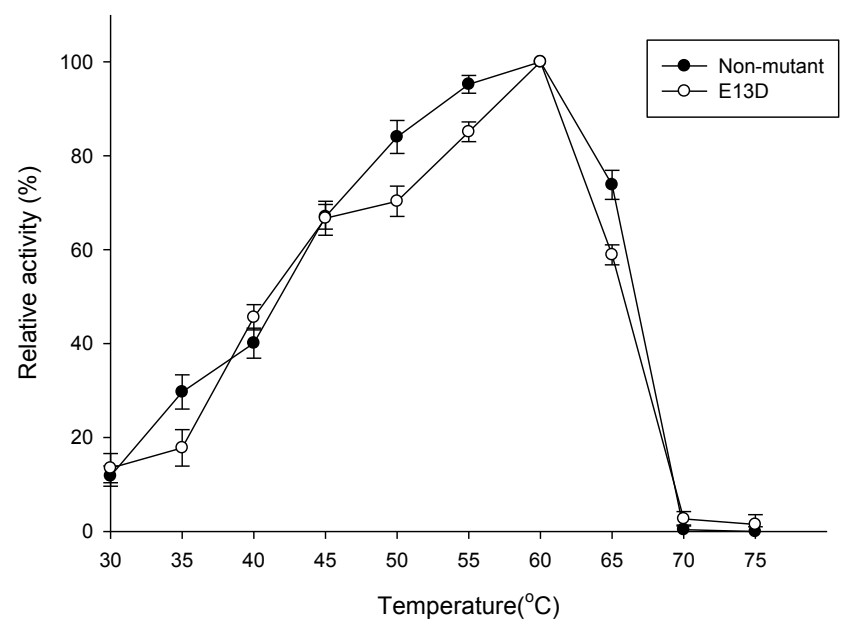

Fig. (5). Effect of temperature on purified proteinase activity. Relative milk-clotting activities (\%) were measured using skim milk as substrate from $30^{\circ} \mathrm{C}$ to $75^{\circ} \mathrm{C}$ for non-mutant MPR and mutant MPR G186D/E13D produced by recombinant yeasts.

\subsection{Effect of Metal Ions and Inhibitors}

The effect of various metal ions on the percent residual activity is shown in Table 4. As shown, $\mathrm{Ca}^{2+}, \mathrm{Mn}^{2+}$, and $\mathrm{Mg}^{2+}$ were activators, whereas $\mathrm{Ni}^{2+}, \mathrm{Fe}^{3+}, \mathrm{Fe}^{2+}$, and $\mathrm{Zn}^{2+}$ were 
inhibitors of the MCA for these enzymes. However, $\mathrm{Cu}^{+}, \mathrm{K}^{+}$ and $\mathrm{Na}^{+}$had no effect on the enzyme activity. Contrary to our results, Wang and others [14] reported that $\mathrm{K}+$ was an inhibitor of the MCA.

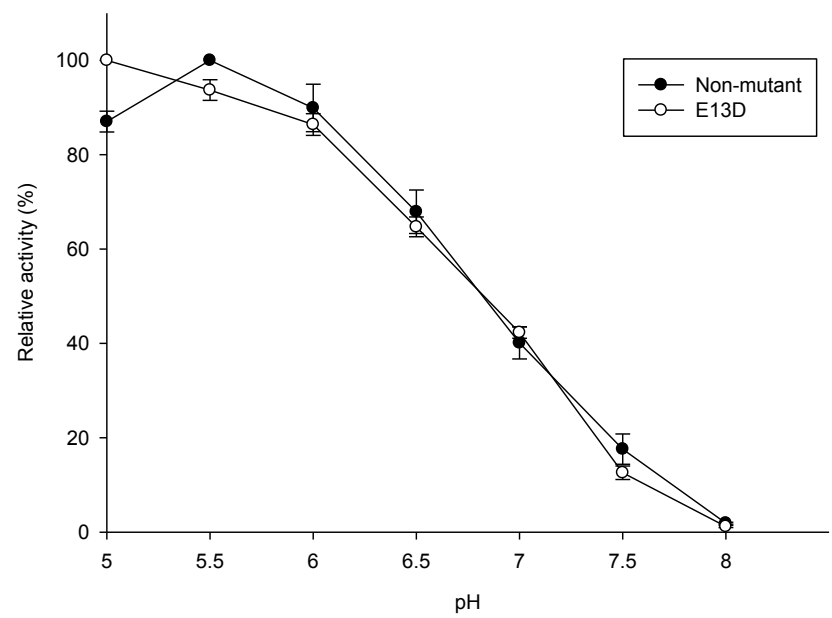

Fig. (6). Effect of $\mathrm{pH}$ on purified proteinase activity. Relative milkclotting activities (\%) were measured using skim milk as substrate from 5.0 to 7.0 for non-mutant MPR and mutant MPRsG186D/ E13D produced by recombinant yeasts.

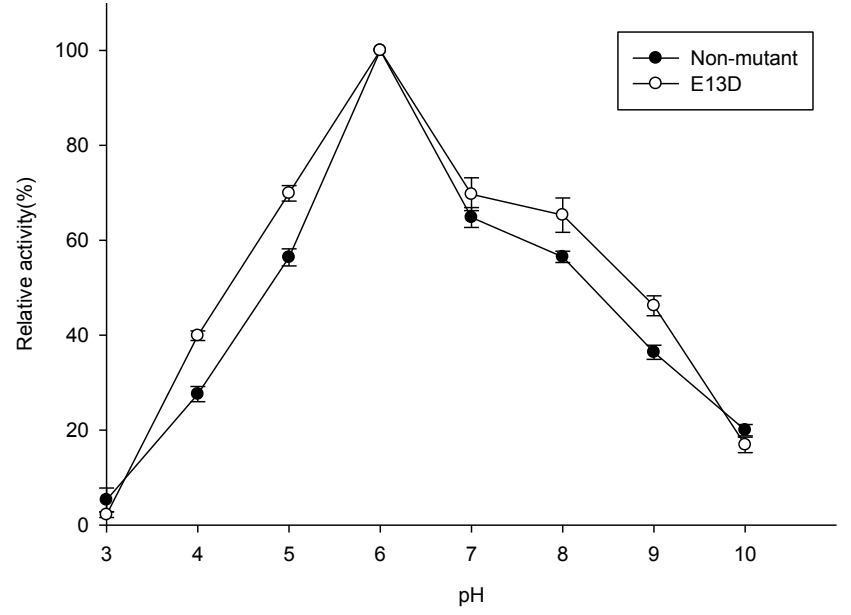

Fig. (7). Stability of proteinase to $\mathrm{pH}$. The non-mutant and mutant MPR were incubated at various $\mathrm{pH}$ values for $4 \mathrm{~h}$ at $25^{\circ} \mathrm{C}$, the residual activities were measured.

Mutant G186D/E13D retained above $90 \%$ of relative activity in the presence of PMSF or aprotin (Table 5), hence serine participation at the active site of the enzyme has also been ruled out. EDTA and aprotinin had little effect on the activity of these enzymes. The protease activity was found to be sensitive to pepstatin, thereby confirming the aspartic protease nature of the activity. But the mutant G186D/E13D was found to be sensitive to 1.10-Phenantrolin, which suggested that these enzymes may be metalloenzyme. However, this result was totally different from other MCPs as reported by Sara [43], Magda [10], Arun [44] and Sushil [12].

\subsection{Textural and Proteolytic Properties of Cheese Made with MPR the Mutants}

The composition and $\mathrm{pH}$ of cheddar cheese made with commercial rennet, non-mutant and mutant rennet (G186D/E13D) with ripening 180d is shown in Table 6. The values for $\mathrm{pH}$, moisture, protein and fat content were in the range 5.16 to $5.21,36.68$ to $38.37 \%, 23.25$ to $26.72 \%$ and 29.25 to $31.53 \%$, respectively. The protein content of nonmutant cheese was marked $(\mathrm{P}<0.05)$ lower than that of mutant rennet cheese whose protein contenthad no significant $(\mathrm{P}<0.05)$ difference with commercial rennet cheese. Similar levels of moisture, fat and $\mathrm{pH}$ were shown between the three cheeses.

Table 4. Effect of metal ions on MCA of purified non-mutant and mutant enzymes.

\begin{tabular}{|c|c|c|}
\hline \multirow{2}{*}{ Metal Ion (5mM) } & \multicolumn{2}{|c|}{ Relative Activity (\%) } \\
\cline { 2 - 3 } & G186D/E13D & Non-Mutant \\
\hline \hline Control & 100 & 100 \\
\hline $\mathrm{Ca}^{2+}$ & 227.6 & 218.8 \\
\hline $\mathrm{Mn}^{2+}$ & 148.3 & 120.7 \\
\hline $\mathrm{Ni}^{2+}$ & 28.7 & 47.8 \\
\hline $\mathrm{Mg}^{2+}$ & 119.5 & 106.8 \\
\hline $\mathrm{Cu}^{+}$ & 96.4 & 100 \\
\hline $\mathrm{K}^{+}$ & 99.8 & 117.3 \\
\hline $\mathrm{Na}^{+}$ & 97.4 & 98.9 \\
\hline $\mathrm{Fe}^{3+}$ & 79.8 & 85.8 \\
\hline $\mathrm{Fe}^{2+}$ & 75.4 & 87.7 \\
\hline $\mathrm{Zn}^{2+}$ & 85.9 & 85.5 \\
\hline Control: $\mathrm{Enzymes} \mathrm{without} \mathrm{adding} \mathrm{metal} \mathrm{ions.}$ & \\
\hline
\end{tabular}

Table 5. Effect of inhibitors on MCA of purified non-mutant and mutant enzyme.

\begin{tabular}{|c|c|c|c|}
\hline \multirow{2}{*}{ Inhibitor } & \multirow{2}{*}{$\begin{array}{c}\text { Concentration } \\
(\mathbf{m m o l} / \mathbf{L})\end{array}$} & \multicolumn{2}{|c|}{ Relative Activity (\%) } \\
\cline { 3 - 4 } & & $\mathbf{G 1 8 6 D / E 1 3 D}$ & Non-Mutant \\
\hline \hline PMSF & 1 & 93.4 & 93.1 \\
\hline 1.10-Phenantrolin & 1 & 0 & 0 \\
\hline Aprotinin & 1 & 73.6 & 72.6 \\
\hline Leupeptin & 0.2 & 95.2 & 96.5 \\
\hline Pepstatin A & 0.05 & 15.2 & 24.5 \\
\hline EDTA & 50 & 77.2 & 71.1 \\
\hline control & 100 & 100 & 100 \\
\hline
\end{tabular}

The level of $\mathrm{pH} 4.6-\mathrm{SN}$ increased with the increase in ripening time in each of the three cheeses. The extent of the increase in $\mathrm{pH} 4.6-\mathrm{SN}$ level was greatest $(\mathrm{P} \leq 0.05)$ in the nonmutant cheese at $180 \mathrm{~d}$ of ripening (Table 6), and there were no obvious differences $(\mathrm{P}<0.05)$ between mutant cheese and 
Table 6. Composition, $\mathrm{pH}$ and $\mathrm{pH}$ 4.6 SN (soluble nitrogen) of Cheddar cheeses made by non-mutant, mutant rennet $(\mathrm{G186D} / \mathrm{E} 13 \mathrm{D})$ and commercial rennet at $180 \mathrm{~d}$ of ripening ${ }^{1}$.

\begin{tabular}{|c|c|c|c|c|c|}
\hline Enzymes & pH & Moisture\% & Protein\% & Fat\% $^{\text {pH4.6 SN\% }}$ \\
\hline \hline Commercial & $5.16(0.03)^{\mathrm{a}}$ & $38.37(0.82)^{\mathrm{a}}$ & $26.72(1.42)^{\mathrm{a}}$ & $31.53(1.17)^{\mathrm{a}}$ & $5.32(0.09)^{\mathrm{a}}$ \\
\hline Non-mutant & $5.16(0.11)^{\mathrm{a}}$ & $37.54(1.12)^{\mathrm{a}}$ & $23.25(0.59)^{\mathrm{b}}$ & $30.92(0.84)^{\mathrm{a}}$ & $6.81(0.24)^{\mathrm{b}}$ \\
\hline G186D/E13D & $5.21(0.02)^{\mathrm{a}}$ & $36.68(0.93)^{\mathrm{a}}$ & $25.29(1.14)^{\mathrm{ab}}$ & $29.25(0.63)^{\mathrm{a}}$ & $5.19(0.18)^{\mathrm{a}}$ \\
\hline
\end{tabular}

${ }^{\mathrm{a}, \mathrm{b}}$ Means within a row with different superscripts are significantly different (Tukey's HSD; $P \leq 0.05$ ).

${ }^{1}$ Values represent means $(\mathrm{SD} ; \mathrm{n}=3)$.

Table 7. Texture profile analysis parameters hardness, cohesiveness, springiness, and chewiness for Cheddar cheeses made with commercial rennet (control), non-mutant rennet, and mutants rennet (G186D/E13D) at $180 \mathrm{~d} \mathrm{of} \mathrm{ripening}^{1}$.

\begin{tabular}{|c|c|c|c|c|}
\hline Enzymes & Hardness (N) & Springiness & Cohesiveness & Chewiness (N) \\
\hline \hline Commercial & $1134.44(12.34)^{\mathrm{a}}$ & $0.39(0.01)^{\mathrm{a}}$ & $0.25(0.01)^{\mathrm{a}}$ & $93.44(5.11)^{\mathrm{a}}$ \\
\hline Non-mutant & $982.11(14.59)^{\mathrm{b}}$ & $0.37(0.01)^{\mathrm{a}}$ & $0.25(0.01)^{\mathrm{a}}$ & $72.13(5.38)^{\mathrm{a}}$ \\
\hline G186D/E13D & $1160.71(16.24)^{\mathrm{a}}$ & $0.36(0.07)^{\mathrm{a}}$ & $0.22(0.01)^{\mathrm{b}}$ & $88.90(6.01)^{\mathrm{a}}$ \\
\hline
\end{tabular}

a, b Means within a row with different superscripts are significantly different (Tukey's HSD; $\mathrm{P}<0.05$ ).

1 Values represent means $(\mathrm{SD} ; \mathrm{n}=3)$.

commercial cheese. The level of the increased pH4.6-SN was greatest in non-mutant cheese, which supports the earlier results showing that the protein content was lowest in non-mutant cheese of $180 \mathrm{~d}$ ripening. Table 7 summarizes the mean values for the parameters obtained in the instrumental texture evaluation. Hardness $(p<0.05)$ of non-mutant cheese was marked lower than that of the mutant cheese. The softening of cheeses was related to the hydration of the protein matrix and the effects of proteolysis [38]. This is in agreement with previous observations in which the level of the increased $\mathrm{pH} 4.6-\mathrm{SN}$ resulted in cheese softening. With respect to springiness, cohesiveness and chewiness, there was no significant difference $(p<0.05)$ between the three cheeses, except for a slight lower inclination of non-mutant rennet cheese with respect to springiness and chewiness.

\section{CONCLUSION}

Site 186 and 13 of MPR are key positions, which relate to temperature sensitivity and substrate specificity. Themostability of MPR decreases remarkably when G186 is substituted by Asp and light reduction of proteolytic activity in MPR happens to be E13, substituted by Glu. Site 186 and 13 belonged to different core regions of MPR. They did not have any influence on each other, which is also proved by mutant G186D/E13D due to the reduction in the thermostability and proteolytic activity simultaneously.

Except for reduction in thermostability and proteolytic activity, the other properties of enzyme of mutant rennet were similar to that of the non-mutated rennet. Most of the textures of cheese made by non-mutated MPR were no different from the other two cheeses, except in protein content, $\mathrm{pH} 4.6-\mathrm{SN}$, hardness and chewiness. Above all, these properties may assure the practical use of this double mutant as an improved milk coagulant. The effective expression system of Pichia pastoris allowing extracellular secretion used in this study will provide a possibility to produce the improved enzyme on large scale.

\section{CONFLICT OF INTEREST}

The authors confirm that this article content has no conflict of interest.

\section{ACKNOWLEDGEMENTS}

The financial support for this work from the Science \& Technology Innovation Project of Jilin Academy of Agricultural Science (ZYCX201315), Science \& Technology Development Project Agreement in Jilin Province (20150307019NY), Jilin Postdoctoral Science Foundation Funded Project (RB201305) is gratefully acknowledged.

\section{REFERENCES}

[1] Maria CVH, Alicia GC, Jesús V, Félix CM. Molecular cloning and expression in yeast of caprine prochymosin. J Biotech 2004; 114 : 69-79.

[2] Kumar A, Sharma J, Mohanty AK, Grover S, Batish VK Purification and characterization of milk clotting enzyme from goat (Capra hircus). Comp Biochem Physiol 2006; B 145: 108-13.

[3] Llorente BE, Brutti CB, Caffini NO. Purification and characterization of a milk-clotting aspartic proteinase from globe artichoke (Cynara scolymus L.). J Agri Food Chem 2004; 52(26): 8182-9.

[4] O'Hara BP, Hemmings AM, Buttle DJ, Pearl LH. Crystal structure of glycyl endopeptidase from Carica papaya: a cysteine endopeptidase of unusual substrate specificity. Biochemistry 1995; 34(40): 13190-5.

[5] Senthilkumar S, Ramasamy D, Subramanian S. Isolation and Partial Characterisation of Milk-clotting Aspartic Protease from Streblus asper. Food Sci Technol Int 2006; 12(2): 103-9.

[6] Domingos A, Cardoso PC, Xue ZT, Clemente A, Brodelius PE, Pais MS. Purification, cloning and autoproteolytic processing of an aspartic proteinase from Centaurea calcitrapa. J Fed Europ Biochem Soci 2000; 267(23): 6824-31.

[7] Egito A, Girardet J, Laguna L, et al. Milk-clotting activity of enzyme extracts from sunflower and albizia seeds and specific hydrolysis of bovine $\kappa$-casein. Int J Technol 2007; 17(7): 816-85.

[8] Kobayashi H, Kim H. Characterization of Aapartic Proteinase from basidiomycete, laetiporus sulphureus. Food Sci Technol Res 2003; 9(1): $30-4$ 
[9] Khan MR, Blain JA, Patterson JDE. Extracellular Proteases of Mucor pusillus. Appl Environ Microbiol 1979; 37(4): 719-24.

[10] Magda AE, Maysa EM, Thanaa HA. Purification and Characterization of Milk Clotting Enzyme Produced by Bacillus sphaericus. J Appl Sci Res 2007; 3(8): 695-9.

[11] Aikawa J, Park YN, Sugiyama M, Nishiyama M, Horinouchi S, Beppu T. Replacements of Amino Acid Residues at Subsites and Their Effects on the Catalytic Properties of Rhizomucor pusillus Pepsin, an Aspartic Proteinase from Rhizomucor pusillus. J Biochem 2001; 129: 791-4.

[12] Sushil K, Neeru SS, Mukh RS, Randhir S. Process Biochem 2005; 40: 1701-1705.

[13] Dunn-Coleman NS, Bloebaum P, Berka RM, et al. Commercial levels of chymosin production by Aspergillus. Biotechnology (NY) 1991; 9: 976-81

[14] Wang YP, Cheng QL, Ahmed Z, Jiang XX, Bai XJ. Purification and partial characterization of milk-clotting enzyme extracted from glutinous rice wine mash liquor. Korean J Chem English 2009; 26(5): 1313-1318

[15] Hiramatsu R, Aikawa J, Horinouchi S, Beppu T. Secretion by Yeast of the Zymogen Form of Mucor Rennin, an Aspartic Proteinase of Mucor pusillus, and Its Conversion to the Mature Form. J Biolog Chem 1989; 264(28): 16862-6.

[16] Beldarraín A, Acosta N, Montesinos R1, Mata M, Cremata J. Characterization of Mucor pusillus rennin expressed in Pichia pastoris: enzymic, spectroscopic and calorimetric studies. Biotechnolog Appl Biochem 2000; 31: 77-84.

[17] Yamashita T, Higashi S, Higashi T, et al. Mutation of a fungal aspartic proteinase, Mucor pusillus rennin, to decrease thermostability for use as a milk coagulant. J Biotechnol 1994; 32 : 17-28.

[18] Fernandez-Lahore HM, Auday RM, Fraile ER, de Jimenez Bonino MB, Pirpignani L, Machalinski C, Cascone O. Purification and characterization of an acid proteinase from mesophilic Mucor sp. solid-state cultures. J Peptide Res 1999; 53(6): 599-605.

[19] Mark GW, Julie W, Phil N, et al. Mutagenesis, biochemical characterization and X-ray structural analysis of point mutants of bovine chymosin. Protein Eng 1997; 10(9): 991-7.

[20] Young NP, Aikawa J, Nishiyama M, Horinouchi S, Beppu T. Involvement of a residue at position 75 in the catalytic mechanism of a fungal aspartic proteinase, Rhizomucor pusulus pepsin. Replacement of tyrosine 75 on the flap by asparagine enhances catalytic efficiency. Protein Eng 1996; 9(10): 869-75.

[21] Chitpinityol S, Goode D, Crabbet MJC. Site-specific mutations of calf chymosin B which influence milk-clotting activity. Food Chem 1998; 62(2): 133-9.

[22] Elena G, Lev R, Lev G, Pavel M. A Natalia. Post X-ray crystallographic studies of chymosin: The existence of two structural forms and the regulation of activity by the interaction with the histidine-proline cluster of $\kappa$-casein. FEBS lett 1996; 379: $60-2$

[23] Lowther WT, Majer P, Dunn BM. Engineering the substrate specificity of rhizopuspepsin: The role of Asp 77 of fungal aspartic proteinases min facilitating the cleavage of oligopeptide substrates with lysine in PI. Protein Sci 1995; 4: 689-702.

[24] Jiang YY, Wang JH, Li YQ, Li D, Yang ZN. Cloning and expression of a rennet gene from mucor pusillus. Dairy Indust China 2010; 38(2): 7-9.

[25] Young NP, Aikawa J, Nishiyama M, Horinouchi S, Beppu T. SiteDirected Mutagenesis of Conserved Trp39 in Rhizomucor pusillus Pepsin: Possible Role of Trp39 in Maintaining Tyr75 in the Correct Orientation for Maximizing Catalytic Activity. J Biochem 1997; 121: 118-21.
[26] Becher DM, Guarente L. High-efficiency transformation of yeast by electroporation. Meth Enzymol 1991; 194: 182-7.

[27] Laemmli UK. Cleavage of structural proteins during the assembly of the head of bacteriophage T. Nature 1970; 227: 680-7.

[28] Sato S, Tokuda H, Koizumi T, Nakanishi K. Purification and characterization of an extracellular proteinase having milk-clotting activity from Enterococcus faecalis TUA2495L. Food Sci Technol Res 2004; 10(1): 44-50.

[29] Alessandro M, Federico F. Partial Purification and Characterization of a Yeast Extracellular Acid Protease. J Dairy Sci 1980; 63: 13971400 .

[30] Chazarra S, Sidrach L, Lopez-Molina D, Rodriguez-Lopez JN Characterization of the milk-clotting properties of extracts from artichoke (Cynara scolymus, L.) flowers. J Int Dairy 2007; 17: 1393-1400

[31] Nuala MR, Thomas PB, Alan LK, Timothy PG. Effect of milk pasteurization temperature and in situ whey protein denaturation on the composition, texture and heat-induced functionality of half-fat Cheddar cheese. J Int Dairy 2004; 14: 989-1001.

[32] O’Mahony JA, Lucey JA, McSweeney PLH. Chymosin-Mediated Proteolysis, Calcium Solubilization, and Texture Development During the Ripening of Cheddar Cheese. J Dairy Sci 2005; 88: 3101-14

[33] AOAC, Association of Official Analytical Chemists International, Official methods of analyses $\left(16^{\text {th }}\right.$ ed $)$, Gaithersburg, Maryland (1997).

[34] AOAC, Association of Official Analytical Chemists International, Official Methods of Analysis (15 ${ }^{\text {th }}$ ed), Arlington, VA (1990).

[35] Muir DD, Banks JM, Hunter EA. A comparison of the Flavour and Texture of Cheddar Cheese of factory of farmhouse origin. J Int Dairy 1997; 7: 485- 97.

[36] St-Gelais D, Lessard J, Champagne CP, Vuillemard JC. Production of fresh Cheddar cheese curds with controlled postacidification and enhanced flavor. J Dairy Sci 2008; 92: 1856-63.

[37] Calvo MV, Castillo I, Diaz-Barcos V, Requena T, Fontech J. Effect of a hygienized rennet paste and a defined strain starter on proteolysis, texture and sensory properties of semi-hard goat cheese. Food Chem 2007; 102: 917-24.

[38] Bhaskaracharya RK, Shah NP. Texture evaluation of commercial mozzarella cheese. Dairy Indust Associ Aus 1999; 54(1): 36-40.

[39] Chirakkal H, Ford GC, Moir A. Analysis of a conserved hydrophobic pocket important for the thermostability of Bacillus pumilus chloramphenicol acetyltransferase (CAT-86). Protein Eng 2001; 14(3): 161-6.

[40] Alsop E, Silver M, Livesay DR. Optimized electrostatic surfaces parallel increased thermostability: a structural bioinformatic analysis. Protein Eng 2003; 16(12): 871-4.

[41] Xiao ZZ, Bergeron $\mathrm{H}$, Grosse $\mathrm{S}$, et al. Improvement of the Thermostability and Activity of a Pectate Lyase by Single Amino Acid Substitutions, Using a Strategy Based on MeltingTemperature-Guided Sequence Alignment. Appl Environ Microbiol 2008; 74(4): 1183-9.

[42] Querol E, Perez-Pons JA, Mozo-Villarias A. Analysis of protein conformational characteristics related to thermostability", Protein Eng 1996; 9(3): 265-71.

[43] Raposo S, Domingos A. Purification and characterization milkclotting aspartic proteinases from Centaurea calcitrapa cell suspension cultures. Process Biochem 2008; 43: 139-44.

[44] A Sharma, A Eapen, SK Subbarao. Purification and characterization of a hemoglobin degrading aspartic protease from the malarial parasite plasmodium vivax. J Biochem 2005; 138: 7178 .

This is an open access article licensed under the terms of the Creative Commons Attribution Non-Commercial License (http://creativecommons.org/licenses/ by-nc/4.0/) which permits unrestricted, non-commercial use, distribution and reproduction in any medium, provided the work is properly cited. 